\title{
Influence of spat origin and environmental parameters on biochemical composition and biometry of the brown mussel Perna perna (Linné, 1758), under culture conditions
}

\author{
Influencia del origen de las semillas y de los parámetros ambientales sobre la composición bioquímica \\ y biometría del mejillón marrón Perna perna (Linné, 1758), bajo condiciones de cultivo \\ Mirle Narváez ${ }^{1}$, Luis Freites ${ }^{1}$, Jeremy Mendoza ${ }^{1}$ and Miguel Guevara ${ }^{1}$ \\ ${ }^{1}$ Departamento de Biología Pesquera, Instituto Oceanográfico de Venezuela, Universidad de Oriente, \\ C. Postal 6101, A. Postal 245, Cumaná, Estado Sucre, Venezuela \\ Ifreitesv@yahoo.es
}

\begin{abstract}
Resumen.- La composición bioquímica, el crecimiento y la supervivencia del mejillón marrón (Perna perna), de orígenes intermareal y submareal fueron comparados después de que ambos grupos fueron colocados en un 'long line', donde crecieron hasta tamaño comercial, en el Golfo de Cariaco, Estado Sucre, Venezuela. Durante el período de muestreo fueron registrados para ambos grupos sus respectivas longitudes, masa seca de los tejidos blandos y de la concha, así como también su condición reproductiva. Los componentes bioquímicos analizados fueron: proteínas, carbohidratos y lípidos. Simultáneamente, se llevaron registros de las condiciones medioambientales representadas por la clorofila $a$, salinidad, temperatura y el seston. Al inicio del período experimental, que duró 213 días, los contenidos de lípidos y carbohidratos fueron significativamente más altos en los mejillones de origen submareal mientras que no hubo diferencias significativas en las proteínas entre ambos grupos de mejillones. Estas diferencias fueron mantenidas hasta el día 15 para los lípidos y el día 21 para los carbohidratos. En contraste, no se observaron diferencias significativas entre ambos grupos en cuanto al crecimiento (longitud y masas de los tejidos blandos) e índice de condición, mostrando así un potencial similar para su cultivo bajo condiciones suspendidas. Con respecto a la influencia de variables medioambientales, la temperatura y clorofila $a$ mostraron una influencia marcada en la composición bioquímica de ambos grupos de mejillones.
\end{abstract}

Palabras clave: Bivalvo, carbohidratos, lípidos, proteínas, reproducción

\section{Introduction}

One of the main reasons why mussel culture has developed exponentially in some parts of the world is due to its establishment in areas where spat availability is abundant (Mason 1976, Hickman 1992). For the brown mussel Perna perna (Linné, 1758) in Venezuela it is expected that, as the commercial culture of this species develops, increased spat demand from rocky shores may

\begin{abstract}
Biochemical composition, growth, and survival of brown mussels (Perna perna) collected from subtidal and intertidal origins were compared after both groups of mussels were placed on a long line and grown to commercial size in Golfo de Cariaco, Sucre state, Venezuela. During the sampling period, data on length, dry mass of soft tissues and shell, as well as reproductive condition were collected for both groups. Proteins, carbohydrates and lipids were the biochemical components analyzed. Simultaneously, environmental conditions represented by chlorophyll $a$, salinity, temperature, and seston were registered. At the beginning of the experimental period, which lasted 213 days, lipid and carbohydrate contents were significantly higher in mussels from subtidal origin while no significant differences were observed in proteins between both mussel groups. These differences were only observed until day 15 for lipids and day 21 for carbohydrates. In contrast, no significant differences were observed between groups in growth (length and mass of soft tissues) and condition index, therefore showing similar potential for their use in suspended culture. Regarding the influence of environmental variables, temperature and chlorophyll $a$ showed the strongest effects on biochemical composition of brown mussels.
\end{abstract}

Key words: Bivalve, carbohydrates, lipids, proteins, reproduction affect the renewal of this important fishery resource. Eventually, the use of artificial collectors for spat fixation, as used, for example, in the culture industry of Mytilus galloprovincialis in Galicia, Spain (Pérez-Camacho et al.1995), could be a viable alternative for increasing spat availability. In the Galician mussel cultures, differential growth in spat has been attributed to heterogeneity in the different sources used. From the initial stages of development of the Galician mussel culture, better growth 
performance was observed for spats from subtidal origin. These differences in growth were attributed to variations in ingestion rates (Pérez-Camacho et al. 1995), which would result from adaptations to marked local variability in the quantity and quality of available seston (Theisen 1977, Bayne et al. 1984, Navarro et al. 1991).

One of the main factors affecting biochemical composition of mussels and other bivalves from temperate intertidal zones is the frequent periods of air exposure, which reduces food availability and has an effect similar to starving (Hummel et al. 1989). For example, Crassostrea gigas individuals subjected to feeding stress (i.e. starving) showed not only a reduction of carbohydrates, but also a decrease of $44 \%$ and $23 \%$ of proteins and lipids, respectively (Whyte et al. 1990). Also, Freites et al. (2003) observed that Mytilus galloprovincialis spat of subtidal origin had larger absolute content of proteins, carbohydrates and glycogen than those of intertidal origin.

Several studies have shown that differences in the biochemical composition of mussel populations located in zones with distinct environmental conditions were due to qualitative and/or quantitative differences in food availability of phytoplanktonic origin (Pérez-Camacho et al. 1995, Fernández-Reiriz et al. 1996, Okumus \& Stirling 1998). With regards to natural populations of mussels of the genus Mytilus spp., annual fluctuations in the different components of the biochemical composition have been related to environmental parameters and the reproductive cycle (Pieters et al. 1979, 1980, Zurburg et al. 1979, De Moreno et al. 1980, Kluytmans et al. 1980, Zandee et al. 1980, Bressan \& Marin 1985, FernándezReiriz et al. 1996, Okumus \& Stirling 1998).

Accordingly, these studies agreed with the theory established by Bayne (1976), whereby after feeding, a series of metabolic processes come into play, from which the energy obtained from the food could be initially accumulated as reserve tissue and thereafter destined for gametogenesis and/or used in periods of low food availability. This would result in a biochemical cycle and, consequently, a reproductive cycle.

In the north-eastern coast of Venezuela, tide levels affect mussels fixed in the upper limit of the intertidal zone, where they may be exposed to air for up to 8 hours in periods of maximum tidal intensity. The main objective of this study was to determine the influence of these environmental conditions on initial biochemical composition and its variations, as well as survival and growth, of spat (subtidal and intertidal origin), placed under culture conditions until attainment of commercial size.

\section{Material and methods}

\section{Spat origin, experimental design, and sampling}

Perna perna spat were collected from a natural bed in

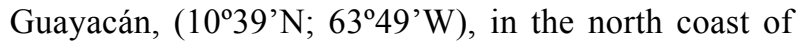
Sucre state, Venezuela (Fig. 1). Spat were manually collected from the subtidal and intertidal rocky shore zones. It was estimated that the latter mussels were exposed at least 8 hours/day and consequently had not been feeding during the exposure time. Both spat groups were transported in insulated containers to the Estación Hidrobiológica de Turpialito (Instituto Oceanográfico de Venezuela - Universidad de Oriente), located at $10^{\circ} 27^{\prime} 30^{\prime \prime} \mathrm{N}$; $64^{\circ} 01^{\prime} 52^{\prime \prime} \mathrm{W}$, on the coast of Golfo de Cariaco, Sucre state (Fig. 1), where they were placed on a long-line culture system $45 \mathrm{~m}$ from the coast at approximately $10 \mathrm{~m}$ depth.

The experimental mussel population from both habitats (subtidal and intertidal) consisted of juveniles with lengths and tissue dry mass varying between 3 and $5 \mathrm{~cm}$ and 0.48 and $0.63 \mathrm{~g}$, respectively. A total of 240 individuals from each habitat were separated randomly in 12 replicates of 20 individuals. These replicates were later attached to $1.5 \mathrm{~m}$ culture lines using biodegradable cotton net. Once attached, the mussels from both origins were suspended at random along the long line at a depth between $2 \mathrm{~m}$ and $3.5 \mathrm{~m}$.

A sample was taken at the beginning of the experiment, later weekly samples were taken during the first month and fortnightly samples during the rest of the study period (from May to October 2003). Each sample collected consisted of a random selection of three experimental replicates from each habitat. These samples were placed in separate plastic bags, and transported to the laboratory for determination of tissue and shell dry mass, total shell height and mussel organic material content and biochemical composition.

\section{Environmental variables}

During mussel sampling water samples were collected with a Niskin bottle, stored in isothermic containers and transported to the laboratory for chlorophyll $a$ and seston analyses. For chlorophyll $a$ determination seawater was pre-filtered through a $250 \mu \mathrm{m}$ sieve and then filtered onto Whatman GF/F $(0.7 \mu \mathrm{m})$ filters with Millipore equipment. Chlorophyll a concentration was obtained using spectrophotometric techniques following methodology described by Strickland \& Parsons (1972). Total seston, including its inorganic and organic fractions, was obtained by the gravimetric method after combustion in a muffle $\left(450^{\circ} \mathrm{C}, 4 \mathrm{~h}\right)$. Salinity was measured in situ using 


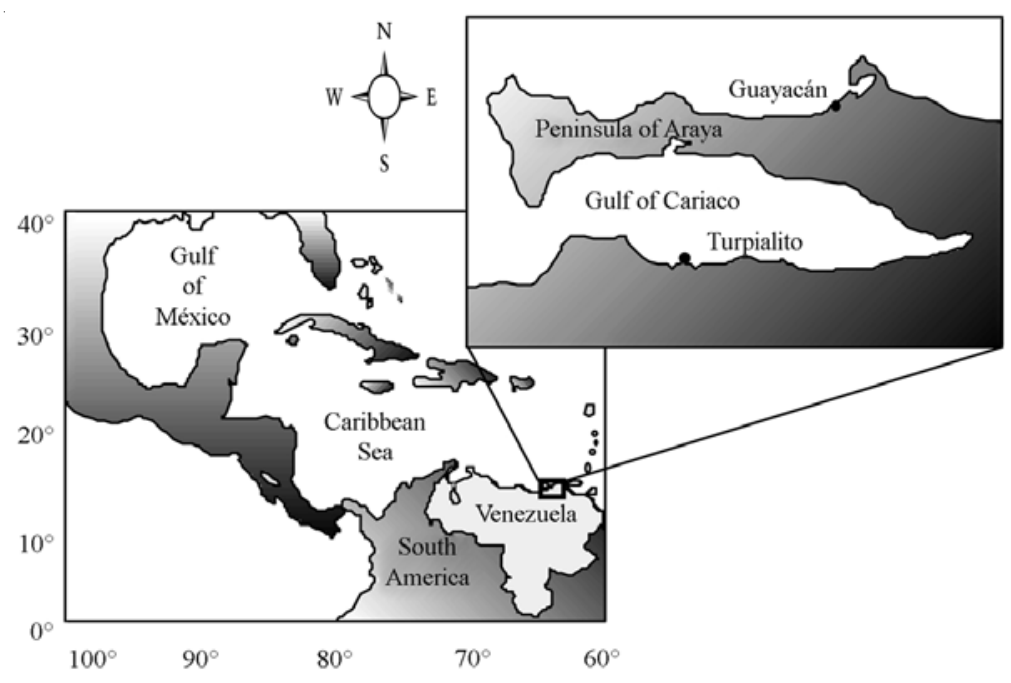

Figure 1

Geographic location of sampling (Guayacán) and culture area of the mussel P. perna (Ensenada de Turpialito)

Ubicación geográfica del área inicial de muestreo (Guayacán) y el área de cultivo del mejillón P. perna (Ensenada de Turpialito)

a hand refractometer ATAGO S/Mill (range 0-100\%o). Temperature was recorded continuously with a Sealog (Vemco Ltd, Halifax) termograph placed at the experimental depth .

\section{Corporal growth of mussel}

Growth of Perna perna spat was estimated from measurements with a digital caliper $(0.01 \mathrm{~mm})$ of total shell height from 3 samples of 15 individuals each from the experimental replicates. To obtain dry mass of soft tissues and shell, these components were placed in previously weighed containers and placed in an oven at $60^{\circ} \mathrm{C}$ until reaching constant weight. Once dried, only the soft tissues were finely ground and stored in a refrigerator for biochemical analysis.

\section{Condition index}

This index was estimated for each individual from the following formula: $\mathrm{CI}=$ (soft tissue dry mass $\mathrm{x} 100$ )/ Total dry mass

\section{Survival of cultured mussels}

Survival was determined from counts of dead individuals at each sampling period.

\section{Reproductive stages of cultured mussels}

Qualitative assessment of reproductive stages was made by identifying morphochromatic gonad characteristics according to the visual scale reported by Nakal (1979), that is: immature (I), developing (II), mature (III), spawned (IV), and gonadal regression (V).

\section{Organic matter}

From each experimental replicate tissue samples from 5 mussels previously oven-dried and weighed were placed in a muffle (JELRUS Two-Stage Temp-Master L) at $450^{\circ} \mathrm{C}$ for 4 hours and organic matter content was calculated from weight differences.

\section{Biochemical analysis}

For the remaining individuals from each experimental replicate, proteins from tissue dry mass were quantified by the method of Lowry et al. (1951), while total lipids were estimated using the gravimetric method following Overturf \& Dryer (1967). Carbohydrates were estimated by the phenol sulphuric method (Dubois et al. 1956). Biochemical composition data were expressed as absolute organic matter content (mg mussel ${ }^{-1}$ ) and relative levels (organic matter percent per mussel). In order to avoid the effects of growth on changes observed in biochemical components content, results were standardized by interpolation to a standard individual of $225 \mathrm{mg}$ (dry tissue mass) which represents the average value between initial and maximum value of mass obtained from both mussels groups (see Fig 3C). 


\section{Statistical analysis}

Biometric, biochemical and environmental variables results were presented in terms of the mean value \pm standard deviation.

The estimates of different parameters for both groups of mussels were compared with a one-way analysis of variance (ANOVA), after testing for homogeneity of variances with Bartlett's test, using a 95\% significance level. When parameter values did not satisfy the condition of variance homogeneity data were transformed to log biomass, arcsine percentage reproductive stages (Zar 1984).

In order to analyze possible relationships between reproductive stages and biochemical composition with environmental parameters Pearson's correlation coefficient and the partial correlation coefficient were used. To account for false positives in a multiple comparison framework and considering the conservative nature and low power of Bonferroni type corrections, the False Detection Rate was assessed by calculating $\mathrm{q}$ values as proposed by Storey (2002). Also, a regression model was used to assess the influence of spat origin and environmental parameters on biochemical composition (carbohydrates, lipids and proteins).

\section{Results}

\section{Environmental variables}

Temperature showed minimum values $\left(25.8^{\circ} \mathrm{C}\right)$ at the end of May and at the beginning of June (Fig. 2A), afterwards there was a sustained increase until maximum values $\left(28.9^{\circ} \mathrm{C}\right)$ were reached in September and remained relatively high until the end of the study period. Salinity mean values in Turpialito showed relatively small variations between $34.00 \pm 0.01$ to $37.67 \pm 0.58$, with minimum values occurring in September (Fig. 2B).

Organic and total seston showed high variability during the experimental period, with minimum values in mid-May and June, beginning of July, and during September (Fig. 2C). A strong increase of total and organic seston, reaching mean values of $11.03 \pm 1.67$, $8.49 \pm 0.61,23.49 \pm 3.68$ and $13.03 \pm 1.11 \mathrm{mg} \mathrm{L}^{-1}$, was observed at the end of June, mid-July, mid-August, and end of October, respectively. Highest chlorophyll $a$ concentrations were observed in the second and third weeks of May with mean values of $6.28 \pm 2.29 \mu \mathrm{g} \mathrm{L}^{-1}$ and $7.06 \pm 0.70 \mu \mathrm{g} \mathrm{L}^{-1}$, respectively (Fig. 2D). These values diminished sharply in the following sample and showed a decreasing trend until the end of the experiment when a minimum of $0.11 \pm 0.04 \mu \mathrm{g} \mathrm{L}^{-1}$ was registered.

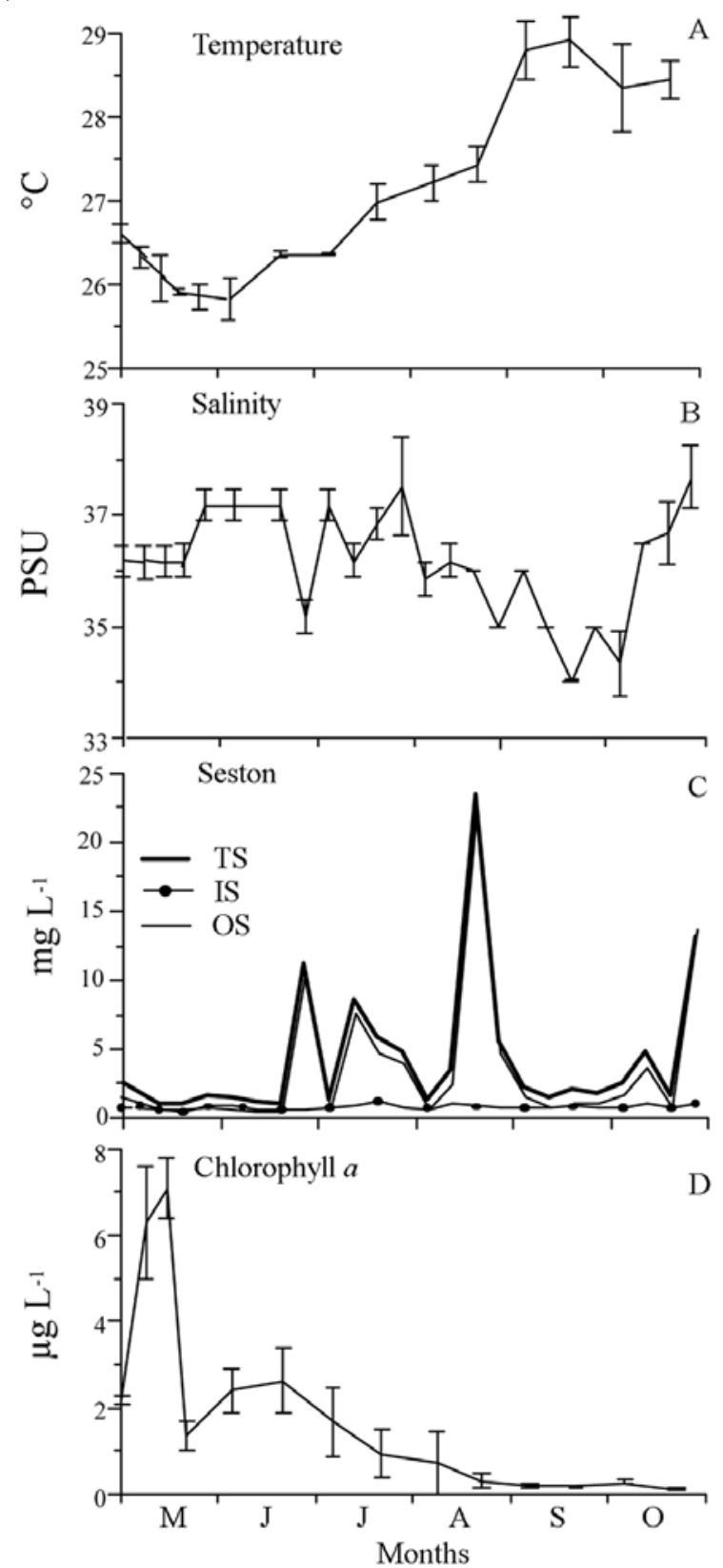

Figure 2

Variations in temperature (A), salinity (B), seston (C) and chlorophyll $a$ (D) during the study period in Ensenada de Turpialito. Horizontal bars represent standard deviation.

TS (total seston), IS (inorganic seston) and OS (organic seston)

Variación de la temperatura (A), salinidad (B), seston (C) y clorofila $a(\mathrm{D})$ durante el lapso de estudio en la Ensenada de Turpialito. Las barras horizontales representan las desviaciones estándar de los datos. TS (seston total), IS (seston inorgánico) and OS (seston orgánico) 


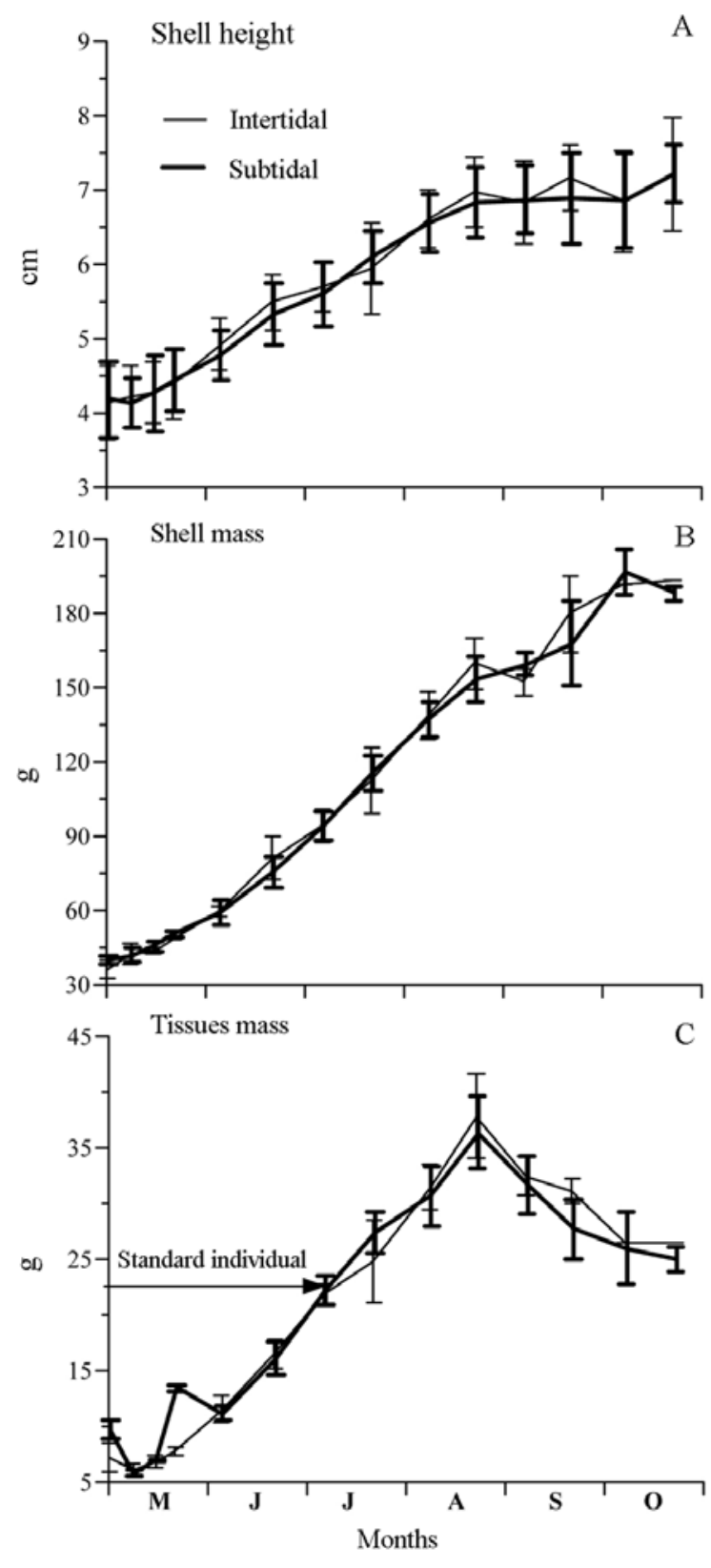

Figure 3

Variation in mean values of shell height (A) shell mass (B) and (C) tissue mass of the mussel P. perna from intertidal and subtidal origin during experimental period in Ensenada de Turpialito. Horizontal bars represent standard deviation

Variación del promedio de la altura de la concha (A) masa de la concha (B) y (C) masa de los tejidos del mejillón P. perna de origen intermareal y submareal, durante el período experimental en la Ensenada de Turpialito. Las barras horizontales representan las desviaciones estándar de los valores

\section{Corporal growth of mussels}

At the beginning of the experiment no significant differences in height and mass were observed between the two groups of spat. The initial mean heights from both origins were $4.13 \pm 0.51 \mathrm{~cm}$ (intertidal) and $4.15 \pm$ $0.51 \mathrm{~cm}$ (subtidal), while initial mean dry shell masses were $35.68 \pm 3.84 \mathrm{~g}$ (intertidal) and $39.22 \pm 1.71 \mathrm{~g}$ (subtidal). At the end of the study period the mussels from intertidal and subtidal habitat origins reached average heights and shell masses of $7.19 \pm 0.76 \mathrm{~cm}$ and $7.20 \pm 0.39 \mathrm{~cm}$ and $193.00 \pm 0.07 \mathrm{~cm}$ and $186.97 \pm 3.05$ $\mathrm{g}$, respectively. In general, growth rate in height was fast during May and August (Fig. 3A); later growth rate showed a decrease for the rest of the study period. In contrast, growth rate of shell dry mass was relatively constant during most of the experiment (Fig. 3B). At the end of the study there were no significant differences between groups in the biometric variables analyzed.

\section{Condition index}

The individuals from subtidal origin showed a significantly higher condition index at the beginning of the study period (ANOVA, $P<0.05$ ). The condition index varied between 11.64 to $19.49 \%$ for subtidal origin and between 12.06 to $19.1 \%$ for intertidal origin (Fig. 4).

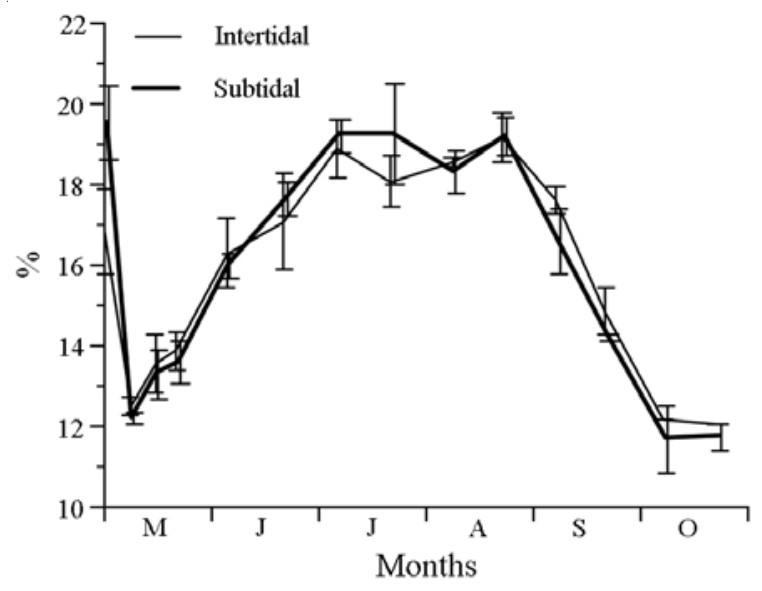

Figure 4

Variation in mean condition index (CI) of the mussel $P$. perna from intertidal and subtidal origin during experimental period in Ensenada de Turpialito. Horizontal bars represent standard deviation

Variación del promedio del índice de condición (IC) del mejillón $P$. perna de origen intermareal y submareal, durante el período experimental en la Ensenada de Turpialito. Las barras horizontales representan las desviaciones estándar de los valores 
However, no significant differences were observed between subtidal and intertidal values of the index after mussels were placed on long-lines in subtidal conditions (Fig. 4). Additionally, this parameter showed for both groups a decrease at the start of the study, an increase to a maximum between July and August and finally a decrease until the end of the experiment.

\section{Survival}

The overall survival of both groups of mussels was greater than $90 \%$ (Fig. 5). Even though individuals of intertidal origin showed a higher survival from June onwards, no statistically significant differences were observed between the two groups during the experimental period. It is worth noting the lower survival rate observed for both groups in the first two weeks of the experimental period, which is likely due to loss of spat not properly attached to the culture rope.

\section{Reproduction}

Both groups of mussels showed a 1:1 sex ratio and sexual development was first apparent at approximately $41 \mathrm{~mm}$ shell length. Spawning occurred during the whole study period (Fig. 6). However, there were two apparent peaks in spawning activity. A first relatively weak spawning event was observed in May, while a much stronger second event was observed between August and October. Additionally, individuals from both origins showed

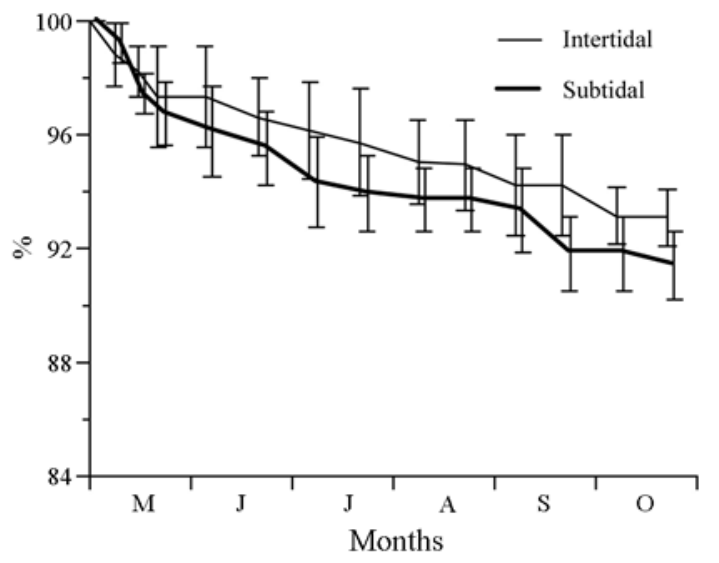

Figure 5

Survival of the mussel $P$. perna from intertidal and subtidal origin in Ensenada de Turpialito. Horizontal bars represent standard deviation

Supervivencia del mejillón $P$. perna de origen intermareal y submareal, en la Ensenada de Turpialito. Las barras horizontales representan las desviaciones estándar de los valores asynchronous reproduction as at least three reproductive stages were present simultaneously during most of the study period.

Relations between reproductive stages and environmental variables

A number of significant Pearson correlation coefficients were observed between the different reproductive stages and environmental variables (Table 1). In particular, there was a direct and highly significant $(\mathrm{q}<0.001)$ correlation between stage IV (spawning) and temperature for both groups of mussels. This suggests that this variable may
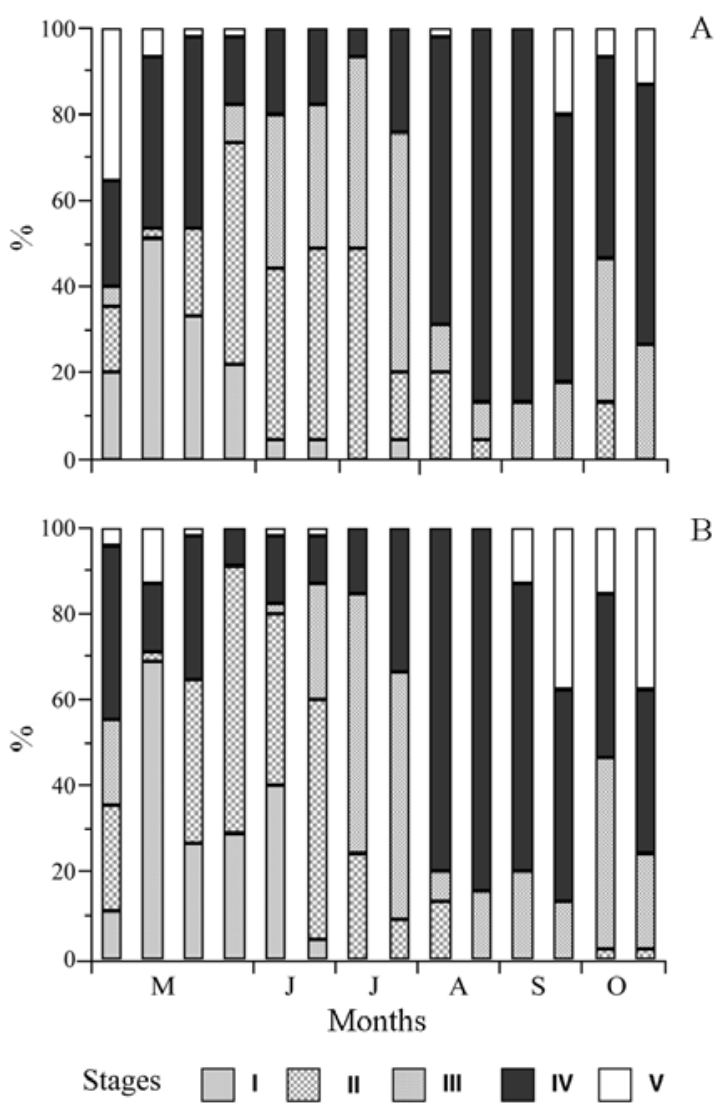

Figure 6

Histograms of reproductive stage frequencies of mussel $P$. perna from intertidal (A) and subtidal (B) origin in Ensenada de Turpialito, Sucre State. Reproductive stages: I=Immature, II=gametogenic stage, III=Mature, IV=Spawning, $\mathrm{V}=$ gonad regression

Histogramas de frecuencia de los estadios reproductivos del mejillón P. perna de origen intermareal (A) y submareal (B) cultivado en la Ensenada de Turpialito, Estado Sucre. Estadios reproductivos: I= Inicio reproductivo, II= Inmaduro, II=Maduro, IV=Desove, $\mathrm{V}=$ Regresión gonádica 
Table 1

Pearson and partial correlation coefficients between reproductive stages and environmental parameters for mussels $P$. perna from intertidal (I) and subtidal (S) origin ( ${ }^{*} \mathbf{q}<0.05$, $\left.* * \mathbf{q}<0.01, * * * \mathbf{q}<0.001\right)$. Values in parenthesis correspond to partial correlation coefficients

Coeficientes de correlación de Pearson y parciales establecidos entre los estadios reproductivos del mejillón $P$. perna de procedencia intermareal (I) y submareal (S) y los parámetros ambientales $\left({ }^{*} \mathrm{q}<0,05,{ }^{*} \mathrm{q}<0,01,{ }^{*} * * \mathrm{q}<0,001\right)$.

Valores en paréntesis corresponden a los coeficientes de correlación parciales

\begin{tabular}{|c|c|c|c|}
\hline & Stage II & Stage III & Stage IV \\
\hline Temperature & $\begin{array}{c}\mathrm{I}-0.770 * * * \\
(-0.284) \\
\mathrm{S}-0.752 * * * \\
(-0.484)\end{array}$ & $\begin{array}{cc}\mathrm{I} & -0.120 \\
& (0.232) \\
\mathrm{S} & 0.176 \\
& (-0.145)\end{array}$ & $\begin{array}{cl}\text { I } \quad 0.500 * * * \\
& (0.237) \\
\text { S } & 0.589 * * * \\
& (0.464)\end{array}$ \\
\hline Salinity & $\begin{array}{c}\text { I } 0.508 * * * \\
(-0.306) \\
\text { S } 0.566^{* * *} \\
(-0.157)\end{array}$ & $\begin{array}{l}\text { I } 0.002 \\
(-0.730)^{* * * *} \\
\text { S }-0.040 \\
(-0.097)\end{array}$ & $\begin{array}{c}\mathrm{I}-0.683 * * * \\
(-0.531)^{*} \\
\mathrm{~S}-0.547^{* * *} \\
(0.201)\end{array}$ \\
\hline Chlorophyll & $\begin{array}{lc}\mathrm{I} & 0.184 \\
& (0.317) \\
\mathrm{S} & 0.360^{*} \\
& (0.150)\end{array}$ & $\begin{array}{ll}\mathrm{I} & -0.225 \\
& (0.177) \\
\mathrm{S} & -0.409 \\
& (0.165)\end{array}$ & $\begin{array}{cl}\mathrm{I} & -0.193 \\
& (0.337) \\
\mathrm{S} & -0.458^{* *} \\
& (-0.160)\end{array}$ \\
\hline Organic seston & $\begin{array}{cc}\mathrm{I} & -0.368^{*} \\
& (0.481) \\
\mathrm{S} & 0.360^{*} \\
(-0.073)\end{array}$ & $\begin{array}{cc}\mathrm{I} & -0.180 \\
& (-0.073) \\
\mathrm{S} & -0.157 \\
& (0.052)\end{array}$ & $\begin{array}{cc}\mathrm{I} & 0.174 \\
& (0.128) \\
\mathrm{S} & -0.251 \\
& (0.056)\end{array}$ \\
\hline Total seston & $\begin{array}{cc}\mathrm{I} & -0.384^{*} \\
(-0.493) \\
\mathrm{S} & 0.367 \\
& (0.062)\end{array}$ & $\begin{array}{cl}\mathrm{I} & -0.174 \\
& (0.051) \\
\mathrm{S} & -0.156 \\
& (-0.063)\end{array}$ & $\begin{array}{c}\mathrm{I} \quad 0.158 \\
(-0.142) \\
\mathrm{S}-0.248 \\
(-0.046)\end{array}$ \\
\hline
\end{tabular}

act as a trigger mechanism for reproductive activity. However, partial correlation coefficients between temperature and reproductive stages were not statistically significant and significant negative partial correlations were only observed between salinity and reproductive stages III and IV of mussels from intertidal origin (Table 1).

\section{Biochemical composition}

Proteins were the biochemical component that showed the highest contents (Fig. 7A). Also, at the start of the sampling period, mussels from the subtidal origin showed significantly higher values of carbohydrates and lipids. This result is more evident for lipids, for which values were twice as high for subtidal individuals when compared to mussels from intertidal origin. These differences for carbohydrates and lipids were observed during the first two or three samples. Afterwards, there were some significant differences for carbohydrates during July and October, but the differences were relatively small.

Furthermore, temporal variations in the biochemical composition of both groups of mussels followed similar patterns during the study period. Proteins showed fluctuations around $1000 \mathrm{mg} \mathrm{mussel}^{-1}$ (Fig. 7A), with decreases in June-July and September-October which may be related to spawning considering the parallel decreases in lipids and increments in spawning activity (see Fig. 6). For carbohydrates, minimum values were observed for both groups of mussels at the onset of the study (Fig. 7B), later these values increased until August and then showed a sustained decrease until the end of the experimental period. In general, protein values remained above $1200 \mathrm{mg} \mathrm{mussel}^{-1}$. Lipids showed similar patterns to those described for proteins, except at the beginning of the experiment when a sharp decrease was observed, especially in individuals of subtidal origin (Fig. 7C). 

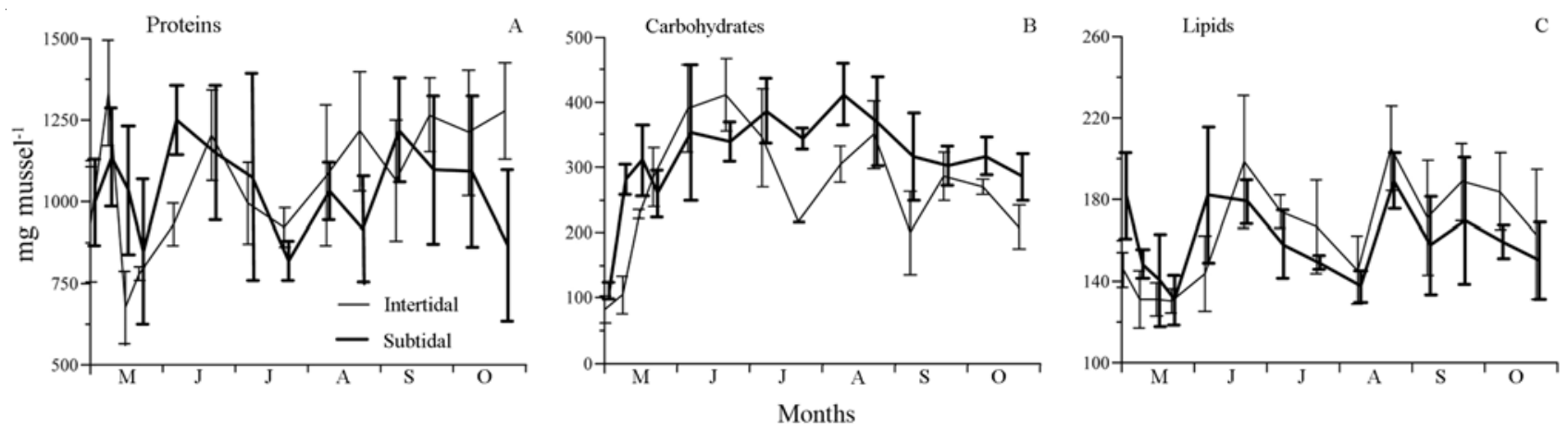

Figure 7

Absolute content (mg mussel ${ }^{-1}$ ) of protein (A), carbohydrate (B), and lipid (C) of the mussel P. perna of intertidal and subtidal origin during the study period in Ensenada de Turpialito. Horizontal bars represent standard deviation

Variación de las proteínas (A), carbohidratos (B) y lípidos (C) expresados en contenidos absolutos (mg mussel ${ }^{-1}$ ) del mejillón $P$. perna de origen intermareal y submareal, ocurrida durante el lapso de estudio en la Ensenada de Turpialito. Las barras horizontales representan las desviaciones estándar de los valores

Table 2

Pearson correlation coefficients between biochemical parameters of the mussel P. perna of intertidal (I) and subtidal (S) origin and environmental variables $\left({ }^{*} \mathbf{q}<0.05, * * \mathbf{q}<0.01, * * * \mathbf{q}<0.001\right)$. Values in parenthesis correspond to partial correlation coefficients

Coeficientes de correlación de Pearson entre los parámetros bioquímicos del mejillón P. perna de procedencia intermareal (I) y submareal (S) y los parámetros ambientales $\left({ }^{*} \mathrm{q}<0,05,{ }^{*} * \mathrm{q}<0,01, * * * \mathrm{q}<0,001\right)$. Valores en paréntesis corresponden a los coeficientes de correlacion parciales

\begin{tabular}{|c|c|c|c|}
\hline & Proteins & Carbohydrates & Lipids \\
\hline \multirow[t]{2}{*}{ Temperature } & $\begin{array}{ll}\mathrm{I} & 0.589^{* * * *} \\
& (0.404)\end{array}$ & $\begin{array}{cc}\mathrm{I} & -0.789 * * * \\
& (-0.133)\end{array}$ & $\begin{array}{cc}\text { I } & 0.037 \\
& (0.270)\end{array}$ \\
\hline & $\begin{array}{c}\text { S } 0.795^{* * *} \\
(-0.310)\end{array}$ & $\begin{array}{c}\mathrm{S}-0.830^{* * *} \\
(0.103)\end{array}$ & $\begin{array}{c}\mathrm{S}-0.402^{* *} \\
(-0.242)\end{array}$ \\
\hline \multirow[t]{2}{*}{ Salinity } & $\begin{array}{lc}\text { I } & 0.042 \\
& (0.150)\end{array}$ & $\begin{array}{l}\mathrm{I} \quad 0.266^{*} \\
(-0.051)\end{array}$ & $\begin{array}{ll}\mathrm{I} & -0.057 \\
& (0.096)\end{array}$ \\
\hline & $\begin{array}{r}S-0.368^{*} \\
(-0.141)\end{array}$ & $\begin{array}{ll}S & 0.462 * * \\
& (0.244)\end{array}$ & $\begin{array}{r}\text { S } 0.079 \\
(-0.183)\end{array}$ \\
\hline \multirow[t]{2}{*}{ Chlorophyll } & $\begin{array}{ll}\mathrm{I} & -0.552^{* * * *} \\
& (0.082)\end{array}$ & 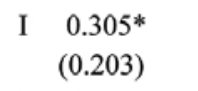 & $\begin{array}{r}\text { I } 0.315^{*} \\
(-0.087)\end{array}$ \\
\hline & $\begin{array}{c}\mathrm{S}-0.656^{* * *} \\
(-0.240)\end{array}$ & $\begin{array}{c}\mathrm{S} \quad 0.401^{* *} \\
(-0.091)\end{array}$ & $\begin{array}{c}\text { S } 0.498 * * * \\
(0.049)\end{array}$ \\
\hline \multirow[t]{2}{*}{ Organic Seston } & I $\begin{array}{r}0.342^{*} \\
(-0.030)\end{array}$ & $\begin{array}{cl}\mathrm{I} & -0.481^{* *} \\
& (0.261)\end{array}$ & $\begin{array}{cc}\text { I } & -0.070 \\
& (-0.001)\end{array}$ \\
\hline & $\begin{array}{ll}S & -0.249 \\
& (0.016)\end{array}$ & $\begin{array}{cc}S & 0.278 \\
& (0.046)\end{array}$ & $\begin{array}{r}\text { S } 0.029 \\
(-0.008)\end{array}$ \\
\hline \multirow[t]{2}{*}{ Total Seston } & $\begin{array}{rr}\text { I } & 0.353^{*} \\
& (0.025)\end{array}$ & $\begin{array}{cl}\mathrm{I} & -0.506 * * * \\
& (-0.265)\end{array}$ & $\begin{array}{ll}\text { I } & -0.044 \\
& (-0.003)\end{array}$ \\
\hline & $\begin{array}{c}\text { S }-0.247 \\
(-0.018)\end{array}$ & $\begin{array}{cc}S & 0.280 \\
(-0.036)\end{array}$ & $\begin{array}{c}\text { S } \quad 0.027 \\
(-0.003)\end{array}$ \\
\hline
\end{tabular}


Table 3

Linear model analysis of carbohydrate, lipid, and protein levels as a function of environmental variables and spat origin of the brown mussel $P$. perna

Análisis del modelo lineal de los niveles de carbohidratos, lípidos y proteínas, como una función de las variables ambientales y del origen de los juveniles del mejillón marrón P. perna

\begin{tabular}{|c|c|c|c|c|}
\hline Variable & Coefficient & Standard error & $\mathrm{t}$ value & $P$ value \\
\hline \multicolumn{5}{|l|}{ Carbohydrates } \\
\hline Intercept & 1296.09 & 210.86 & 6.15 & $3.14 \times 10^{-8}$ \\
\hline Temperature & -38.78 & 3.64 & 10.66 & $6.91 \times 10^{-17}$ \\
\hline Chlorophyll $a$ & -117.02 & 43.78 & 2.67 & $9.15 \times 10^{-3}$ \\
\hline Salinity & -1.38 & 3.51 & 0.39 & 0.69 \\
\hline Total Seston & 16.86 & 47.83 & 0.35 & 0.72 \\
\hline Origin & 5.01 & 2.61 & 1.92 & 0.06 \\
\hline \multicolumn{5}{|l|}{ Lipids } \\
\hline Intercept & -115.93 & 422.77 & 0.27 & 0.78 \\
\hline Temperature & 3.81 & 7.29 & 0.52 & 0.60 \\
\hline Chlorophyll $a$ & 323.91 & 87.78 & 3.69 & $4.13 \times 10^{-4}$ \\
\hline Salinity & -5.13 & 7.03 & 0.73 & 0.47 \\
\hline Total Seston & 77.08 & 95.90 & 0.80 & 0.42 \\
\hline Origin & 5.48 & 5.23 & 1.05 & 0.30 \\
\hline \multicolumn{5}{|l|}{ Proteins } \\
\hline Intercept & -1119.40 & 376.04 & 2.98 & $3.88 \times 10^{-3}$ \\
\hline Temperature & 38.33 & 6.48 & 5.91 & $8.47 \times 10^{-8}$ \\
\hline Chlorophyll $a$ & -249.91 & 78.08 & 3.20 & $1.98 \times 10^{-3}$ \\
\hline Salinity & 15.02 & 6.26 & 2.40 & $1.88 \times 10^{-2}$ \\
\hline Total Seston & -142.75 & 85.30 & 1.67 & 0.10 \\
\hline Origin & -12.76 & 4.65 & 2.74 & $7.54 \times 10^{-3}$ \\
\hline
\end{tabular}

\section{Relations between biochemical components and environmental variables}

Several significant correlations were observed between biochemical components and environmental variables (Table 2). Particularly, positive relationships were observed between proteins and temperature and between chlorophyll $a$, carbohydrates, and lipids, while strong negative relationships appeared between temperature and carbohydrates and between chlorophyll and proteins. Most of the estimated correlations were of the same sign and similar values for both spat origins. However, these relationships did not hold when partial correlation coefficients were estimated between biochemical components and environmental variables (Table 2).

\section{Influence of environmental variables and spat origin on biochemical composition}

The linear models indicated that temperature and chlorophyll $a$ had the strongest effect on biochemical composition (Table 3). Particularly, chlorophyll $a$ presented relatively large negative effects on carbohydrates and protein and a relatively large positive effect on lipids, representing the only environmental variable statistically related to this biochemical group. The effects of temperature on carbohydrates and proteins were highly significant, but the effect was not as large as that of chlorophyll $a$, while spat origin had a significant negative effect on protein content only. All regression models were statistically significant, especially for carbohydrates (multiple $\mathrm{R}^{2}=0.69 ; \mathrm{F}_{(5,78)}=34.23 ; P=$ $2.38 \times 10^{-18}$ ) and proteins (multiple $\mathrm{R}^{2}=0.60 ; \mathrm{F}_{(5,78)}=$ 23.60; $P=2.28 \times 10^{-14}$ ) and less so for lipids (multiple $\mathrm{R}^{2}$ $\left.=0.20 ; \mathrm{F}_{(5,78)}=3.83 ; P=3.70 \times 10^{-3}\right)$.

\section{Discussion}

Results show that at the beginning of the study period, mussels from subtidal and intertidal origins showed no significant differences in initial absolute values of protein in contrast with significant differences in absolute values 
of carbohydrates and lipids, differences that remained for at least the first 15 days. These results correspond with previous studies in which the biochemical composition of bivalves reflects conditions prevailing in the habitats where initial development occurs (Whyte et al. 1990, Napolitano et al. 1992, Fernández-Reiriz et al. 1996, Okumus \& Stirling 1998).

However, mussels from both groups showed no significant differences in the biometric variables analyzed (height, dry masses shell, and condition index) throughout the study period. These results contrast with those obtained by Babarro et al. (2000) in which mussels from subtidal origin reached significantly higher lengths at the end of their study. In our study, both groups of mussels attained commercial sizes in only six months of culture, despite restricted growth in length and soft tissue dry mass during the last two months (September-October).

The observed decrease in growth rates, shell length and condition index during the last months of the experimental period may have been due to low food availability of phytoplanktic origin. In general, the results obtained agree with other growth studies of different species of bivalves in the same location and period where reduced growth is associated to high temperatures and low food availability (Lodeiros et al. 1993, Lodeiros \& Himmelman 1994, Freites \& Núñez 2001). Another possible cause of the decrease in dry mass and condition index of both groups of mussels observed in SeptemberOctober may be related to reproduction and the subsequent loss of biomass in the form of gametes. Ansell et al. (1980) and Mathieu \& Lubet (1993) report that reproduction in different species of mussels is associated with considerable energy expenditure and that biomass loss during spawning may reach values between 30 and $60 \%$.

Regarding survival, the cumulated value of this variable remained above $91 \%$ at the end of the study despite the initial mortality associated with inadequate fixing of spat to the long-line ropes. These relatively high survival rates $(>91 \%)$ represent an added element to the suspended culture potential of this species in Golfo de Cariaco.

The analysis of reproductive stage frequencies showed that spawning (stage IV) occurred during most of the study period, with a higher proportion occurring between July and October. These results coincide with the studies by Carvajal (1969), Vélez (1971) and Prieto et al. (1999) for the same species. Another important characteristic of this species is the temporal coexistence of individuals in different reproductive stages. In some samples all reproductive stages were present, which is indicative that Perna perna shows asynchronous reproduction. Other tropical bivalve species such as Nodipecten nodosus (Vélez et al. 1987) have been shown to exhibit this type of reproduction, which contrasts with temperate species that are generally characterized by synchronic reproduction (Román et al. 2001).

The higher carbohydrate and lipid contents and condition index of subtidal mussels at the onset of the study indicate the more favorable conditions prevailing in this habitat, as they probably were not affected by stress factors such as direct solar radiation, high temperatures, and starvation. Additionally, while no significant differences were observed when comparing initial protein contents of both groups of mussels, the linear model analysis indicated a slight negative effect of subtidal origin on protein content. These results can be contrasted with the study by Freites et al. (2003), in which individuals of Mytilus galloprovincialis from intertidal origin showed significantly higher protein content during the first 36 days of the experiment, while higher carbohydrate levels were observed in subtidal mussels during at least 7 more days than in the present study. These differences between both species may be due to the longer exposure period related to wider tidal fluctuations for the temperate species. However, it can not be discounted that these differences may also be related to food quantity and quality in different environments and/or with species-specific mechanisms for capturing, ingesting, and assimilating food.

Carbohydrates were the second-most important component in terms of absolute content (see Fig. 7). Carbohydrate content presented a progressive increase from the beginning of the experiment (May) until August and then a decrease for the rest of the study period. The observed decrease was probably related to low food availability of phytoplanktic origin observed during the period August-October (see Fig. 3D). This agrees with results presented by Zandee et al. (1980) and Okumus \& Stirling (1998), who also observed in the mussel Mytilus edulis a decrease in carbohydrates and lipids during periods of low food availability. However, we can not discount that the observed decrease in carbohydrate levels may have been caused by the high temperatures registered during the August-October period. According to Cognetti et al. (2001), high temperatures increase metabolic rates and consequently carbohydrate consumption in poikilothermic invertebrates. In this context it is worth noting that the linear model of carbohydrate content as a function of environmental variables showed significant negative effects of temperature and chlorophyll. However, the negative effect of chlorophyll in this model may be explained by collinearity between this variable and temperature, as a linear model (not shown) of carbohydrates as a function of chlorophyll showed a 
significant positive effect.

Chlorophyll appeared as the main environmental variable with a significant direct relationship with lipid content. In general, the range of variations and trends of lipid content in both groups of mussels were similar, except for the higher levels in subtidal mussels at the start of the experiment. Both groups of mussels presented an initial decrease, albeit of different magnitude, in lipid content which may be related to the experimental manipulation to which they were submitted. After this initial decrease, two periods of accumulation and reduction of lipids were observed which occur with parallel processes of gametogenesis/reproductive maturity and spawning, respectively. This suggests that changes in content may have been related to the formation of gametogenic tissue (structural lipids) and/or the accumulation of energetic reserves in gametes (neutral lipids), while reductions were probably related to spawning. Also, protein content decreases have been observed as a result of spawning activities in the bivalves Mytilus edulis (Zandee et al. 1980), Mytilus galloprovincialis (Bressan \& Marin 1985), Argopecten irradians irradians (Epp et al. 1988), Ostrea edulis (Ruiz et al. 1992) and Crassostrea iridescens (Páez-Osuna et al. 1993).

Finally, despite the initial significantly higher carbohydrate and lipid content of subtidal mussels, the observed differences in biochemical composition between both groups did not extend beyond the first three weeks of the culture experiment. Also, considering that no differences were observed in growth (length and mass) and condition index between both groups, the high percent survival $(>90 \%)$, and the attainment of commercial size in only 6 months, are all indicative of the high potential of the mussel Perna perna for commercial culture in Golfo de Cariaco.

\section{Acknowledgments}

The authors would like to thank Consejo de Investigación de la Universidad de Oriente for economic support under project $\mathrm{N}^{\circ}$ CI-5-1802-1159/03. We are indebted to Maximiano Núñez for technical assistance and the personnel of the Estación Hidrobiológica de Turpialito who provided facilities for our experiments. Also we are indebted to MSc. Berenice Licet for her experience in the classification of mussel sexual stages.

\section{Literature cited}

Ansell AD, L Frenkiel \& M Moueza. 1980. Seasonal changes in tissue weight and biochemical composition for the bivalve Donax trunculus L. on the Algerian coast. Journal of Experimental Marine Biology and Ecology 45: 105-116.
Arrieche D, B Liceo, N García, C Lodeiros \& A Prieto. 2002. Índice de condición, gonádico y de rendimiento del mejillón marrón Perna perna (Bivalvia: Mytilidae), del Morro de Guacarapo, Venezuela. Interciencia 27(11): 613619.

Babarro JMF, MJ Fernández-Reiriz \& U Labarta. 2000. Growth of seed mussel (Mytilus galloprovincialis Lmk): Effects of environmental parameters and seed origin. Journal of Shellfish Research 19: 187-193.

Bayne B. 1976. Aspects of reproduction in bivalve mollusks. In: Wiley ML(ed). Estuarine Processes. 1: 1-541. Academic Press, London.

Bayne BL, DW Klumpp \& KR Clarke. 1984. Aspects of feeding, including estimates of gut residence time, in three mytilid species (Bivalvia, Mollusca) at two contrasting sites in the Cape Peninsula, South Africa. Oecologia 64: 26-33.

Bressan M \& G Marin. 1985. Seasonal variation in biochemical composition and condition index of culture mussels (Mytilus galloprovincialis Lmk) in the Venice Lagoon (North Adriatic). Aquaculture 48: 13-21.

Carvajal J. 1969. Fluctuación mensual de las larvas y crecimiento del mejillón Perna perna (L) y las condiciones ambientales de la Ensenada de Guatapanare, Edo. Sucre Venezuela. Boletín del Instituto Oceanográfico de Venezuela 8: $13-20$

Cognetti G, M Sará \& G Magazú. 2001. Biología Marina, 619 pp. Ariel Ciencia, Barcelona.

De Moreno, JEA, RJ Pollero, VJ Moreno \& RR Brenner. 1980. Lipids and fatty acids of the mussel (Mytilus platensis d'Orbigny) from South Atlantic waters. Journal of Experimental Marine Biology and Ecology 48: 263-276.

Dubois M, KA Gilles, JK Halmilton, PA Rebers \& F Smith. 1956. Colorimetric method for determination of sugars and related substances. Analytical Chemistry 28: 350-356.

Epp J, MV Bricelj \& RE Malouf. 1988. Seasonal partitioning and utilization of energy reserves in two age classes of the bay scallop Argopecten irradians (Lamarck). Journal of Experimental Marine Biology and Ecology 121: 113-136.

Fernández-Reiriz MJ, U Labarta \& JMF Babarro. 1996. Comparative allometries in growth and chemical composition of mussel (Mytilus galloprovincialis, Lmk.) cultured in two zones in the Ría Sada (Galicia, NW Spain). Journal Shellfish Research 15(2): 349-353.

Freites L \& M Núñez. 2001. Cultivo suspendido de Lyropecten (nodipecten) nodosus (L., 1758) mediante los métodos de bolsas y aurículas ('Ear hanging'). Boletín del Instituto Oceanográfico de Venezuela 40: 21-29.

Freites L, MJ Fernández-Reiriz \& U Labarta. 2003. Composición bioquímica y contenido energético del mejillón Mytilus galloprovincialis de origen submareal e intermareal: Influencia de las variables ambientales y de su origen. Ciencias Marinas 29(4B): 603-619. 
Gabbott P. 1976. Energy metabolism. In: Bayne BL (ed). Marine mussels: Their ecology and physiology, pp. 293-356. Cambridge University Press, Cambridge.

Gabbott P. 1983. Developmental and seasonal metabolic activities in marine mollusks. In: Hochachka P (ed). The Mollusca. Vol 2: Enviromental Biochemistry and Physiology, pp. 165-217. Academic Press, New York.

Hickman RW. 1992. Mussel cultivation. In: Gosling E (ed). The mussel Mytilus: ecology, physiology, genetics and culture, pp. 465-510. Elsevier Sciences Publishers, Amsterdam.

Holland DL. 1978. Lipid reserves and energy metabolism in the larvae of benthic marine invertebrates. In: Sargent DC \& JR Malins (eds). Biochemical and biophysical perspectives in marine biology 4: 85-123. Academic Press, London.

Hummel H, L de Wolf, W Zurburg, LApon, RH Bogaards \& M van Ruttenburg. 1989. The glycogen content in stressed marine bivalves: the initial absence of a decrease. Comparative Biochemistry and Physiology 4: 729-733.

Lodeiros CJ \& JH Himmelman. 1994. Relations among environmental conditions and growth in the tropical scallop Euvola (Pecten) ziczac (L.) in suspended culture in the Golfo de Cariaco, Venezuela. Aquaculture 119: 345358.Lodeiros C, L Freites, M Núñez \& J Himmelman. 1993. Growth of the Caribbean scallop Argopecten nucleus (Born 1780) in suspended culture. Journal of Shellfish Research 12: 291-294.

Lowry OH, NJ Rosebrough \& AL Fair. 1951. Protein measurement with the folin phenol reagent. Journal of Biological Chemistry 193: 265-275.

Lubet P. 1984. Biologie de la reproduction de mollusques bivalves d'importance commerciale en Mediterranée. Haliotis 14: 49-68.

Lubet P \& R Mann. 1987. Les différentes modalités de la reproduction chez les mollusques bivalves. Haliotis 16: 181195.

Mason J. 1976. Cultivation. In: Bayne BL (ed). Marine mussels: their ecology and physiology, pp. 385-410. Cambridge University Press, Cambridge.

Mathieu M \& P Lubet. 1993. Storage tissue metabolism and reproduction in marine bivalves a brief review. Invertebrate Reproduction and Development 23: 123-129.

Nakal A. 1979. Contribución a la ecología de la pepitona Arca zebra (Swanson, 1833). Aspectos gametogénicos. Trabajo de Grado Licenciado en Biología, Universidad de Oriente, Cumaná, 85 pp.

Napolitano GE, BA MacDonald, RJ Thompson \& RG Ackman. 1992. Lipid composition of eggs and adductor muscle in giant scallops Placopecten magellanicus from different habitats. Marine Biology 113: 71-72.
Narváez N, C Lodeiros, L Freites, M Núñez, D Pico \& A Prieto. 2000. Abundancia de juveniles y crecimiento de Pinna carnea (Mytiloida: Pinnacea) en cultivo suspendido. Revista de Biología Tropical 48: 785-797.

Navarro E, JIP Iglesias, A Pérez-Camacho, U Labarta \& R Beiras. 1991. The physiological energetics of mussels (Mytilus galloprovincialis Lmk) from different cultivation rafts in the Ría Arosa (Galicia, NW. Spain). Aquaculture 4: 197-212.

Okumus I \& HP Stirling. 1998. Seasonal variations in the weight, condition index and biochemical composition of mussels (Mytilus edulis, L.) in suspended culture in two Scottish sea lochs. Aquaculture 159: 249-261.

Overturf M \& R Dryer. 1967. Experiment in the biochemistry of animal lipids. In: Kerkut G (ed). Experiments in physiology and biochemistry 2: 81-163. Academic Press, New York.

Páez-Osuna F, HM Zazagueta-Padilla \& JI Osuna-López. 1993. Biochemical composition of the oysters Crassostrea iridescens Hanley and Crassostrea cortezienzis Hertlein in the Northwest coast of Mexico: seasonal changes. Journal of Experimental Marine Biology and Ecology 170: 1-9.

Pereira R, A Prieto \& M Flores. 1988. Notas sobre el crecimiento en una población del mejillón Modiolus squamosus en Tucuchare, Golfo de Cariaco Venezuela. Acta Científica Venezolana 39: 281-288.

Pérez-Camacho A, U Labarta \& R Beiras. 1995. Growth of mussels (Mytilus edulis galloprovincialis ) on cultivation rafts: influence of seed source, cultivation site and phytoplankton availability. Aquaculture 138: 349-362.

Pieters H, JH Kluytmans, W Zurburg \& DI Zandee. 1979. The influence of seasonal changes on energy metabolism in Mytilus edulis L. I. Growth rate and biochemical composition in relation to enviromental parameters and spawning. In: Naylor E \& RG Hartnoll (eds). Cyclic phenomena in marine plants and animals, pp. 285-292. Pergamon Press, New York.

Pieters H, JH Kluytmans, DI Zandee \& GC Cadée. 1980. Tissue composition and reproduction of Mytilus edulis in relation to food availability. Netherlands Journal of Sea Research 14: 349-361.

Prieto A, M Vásquez \& L Ruiz. 1999. Dinámica energética del crecimiento en una población del mejillón Perna perna (Filibranchia: Mytilidae) en el noreste del Estado Sucre, Venezuela. Revista de Biología Tropical 47(3): 399-410.

Román G, G Martínez, O García \& L Freites. 2001. Reproducción. In: Maeda-Martínez AN (ed). Los moluscos Pectínidos de Iberoamérica. Ciencia y Acuicultura 2: 2759.

Ruiz C, D Martínez, G Mosquera, M Abad \& JL Sánchez. 1992. Seasonal variations in condition, reproductive activity 
and biochemical composition of the flat oyster, Ostrea edulis, from San Cibran (Galicia, Spain). Marine Biology 112: $67-74$

Storey JD. 2002. A direct approach to false discovery rates. Journal of the Royal Statistical Society Series B 64(Part 3): 479-498.

Strickland JD \& TR Parsons. 1972. A practical handbook of seawater analysis. Bulletin of the Fisheries Research Board of Canada 167: 1-310.

Theisen BF. 1977. Feeding rate of Mytilus edulis L. (Bivalvia) from different parts of Danish waters in water of different turbity. Ophelia 16: 221-232.

Vélez A. 1971. Fluctuación mensual del índice de engorde del mejillón Perna perna natural y cultivado. Boletín del Instituto Oceanográfico de Venezuela 10: 3-8.

Vélez A, F Sotillo \& J Pérez. 1987. Variación estacional de la composición química de los pectinidos Pecten ziczac y Lyropecten nodosus. Boletín del Instituto Oceanográfico de Venezuela 26: 67-72.
Whyte JNC, JR Englar \& BL Carswell. 1990. Biochemical composition and energy reserves in Crassostrea gigas exposed to different levels of nutrition. Aquaculture 90: 157-172.

Zandee DI, JH Kluytmans, W Zurburg \& H Pieters. 1980. Seasonal variations in biochemical composition of Mytilus edulis (L.) with reference to energy metabolism and gametogenesis. Netherlands Journal of Sea Research 14(2): $1-29$.

Zar JH. 1984. Biostatistical analysis, 718 pp. Prentice-Hall, Englewood Cliffs.

Zurburg W, JH Kluytmans, H Pieters \& DI Zandee. 1979. The influence of seasonal changes on energy metabolism in Mytilus edulis (L.). II. Organ specificity. In: Naylor E \& RG Hartnoll (eds). Cyclic phenomena in marine plants and animals, pp. 293-300. Pergamon Press, New York.

Recibido el 8 de octubre de 2008 y aceptado el 16 de abril de 2009 